Pak. j. sci. ind. res. Ser. B: biol. sci. 201558 (1) 30-39

\title{
Turkey-Hen Amino Acid Composition of Brain and Eyes
}

\author{
Emmanuel Ilesanmi Adeyeye \\ Department of Chemistry (Analytical Unit), Ekiti State University, PMB 5363, Ado-Ekiti, Nigeria
}

(received February 11, 2014; revised June 19, 2014; accepted August 29, 2014)

\begin{abstract}
The amino acids composition of the brain and eyes of the mature Turkey-hen (Meleagris gallopavo L.), were determined on dry weight basis. Total essential amino acids ranged from 35.1-36.0 g/100 g as 49.5$49.8 \%$ of the total amino acids. The amino acid score showed that lysine ranged from $0.76-0.91$ (on whole hen's egg comparison), 0.85-1.03 (on provisional essential amino acid scoring pattern), and 0.81-0.98 (on suggested requirement of the essential amino acid of a preschool child). The predicted protein efficiency ratio was 1.94-2.41, whilst essential amino acid index range was 1.06-1.08 and the calculated isoelectric point range was 3.97-4.18. The correlation coefficient $\left(r_{x y}\right)$ was positively high and significant at $r=0.01$ for the total amino acids, amino acid scores (on the whole hen's egg comparisons made) and the isoelectric point. On the whole, the eyes were better in $12 / 18$ or $66.7 \%$ parameters of the amino acids than the brain of Turkey-Hen.
\end{abstract}

Keywords: amino acids, brain, eyes, turkey-hen

\section{Introduction}

Turkey with reference to birds, was originally a prefix to the terms cock, hen and poult (a young bird), but now stands on its own and denotes the species Meleagris gallopavo. Native to North America, these birds are now farmed and used for table poultry around the globe (Schorger, 1966).

The nomenclature of Turkey in modern European languages and scientific Latin, reflects confusion about the origin and nature of the bird on their arrival from the new world. They were confused in European minds with guinea-fowl, and probably peacocks too. Linnaeus used Meleagris, the Roman name for guinea-fowl, when naming the genus to which turkeys belong. Europeans called turkeys by names reflecting a supposed eastern origin, including coq d'Inde (cock of India), later corrupted to dinde or dindon in French. The English, who may have had their first birds through the agency of the Levant or Turkey merchants, settled on Turkey-cock (Davidson, 1999).

In their natural state they live in flocks, roosting in swampy areas and feeding on woodland berries and seeds. They are awkward in flight but run fast. It is thought to have been domesticated late in the $2^{\text {nd }}$ millennium BC, somewhere, in Central America. By the time of the Spanish conquest, it was reared as a table bird and eaten by royalty. The earliest full description of turkeys in the new world was given by Shagún (1590) who recommended the meat of the hen as fat

E-mail: eiadeyeye@yahoo.com and savoury, and recorded several modes of preparation, including in TAMALES (Davidson, 1999).

Due to the emphasis placed on the nutritive value of food by consumers, a great need exists for information on the nutritional qualities of Turkey meat. Some work has been reported on different organs analyses of the Turkey-hen. Adeyeye and Ayejuyo (2007) reported on the proximate, amino acid and mineral composition of Turkey-hen muscle and skin; effect of salts on the food properties of Turkey-hen (Meleagris gallopavo L.) muscle flour (Adeyeye, 2011a); comparative study on the characteristics of egg shells of some bird species (including turkey) (Adeyeye, 2009a); determination of amino acids profiles of the organ meats of the Turkeyhen (Adeyeye, 2012) and the comparison of the amino acids profiles of whole eggs of duck, francolin and Turkey consumed in Nigeria (Adeyeye, 2013). In this part of the world, the head of the Turkey is usually reserved and given to the preschool child (2-5 years old) for consumption after cooking. The present study was therefore, undertaken in attempt to gain some information on the amino acid of the head organs (brain and eyes) of Turkey-hen. The Turkey sample used was the white plumage Turkey-hen bird.

\section{Materials and Methods}

Preparation of samples. Prior to butchering, food was withheld for a day to help ensure the digestive system was empty. Head was held on the stump and the Turkey head removed with an axe. At the end of bleeding, the Turkey was plucked. When all the feathers had been 
removed, the head was rinsed and dried in the oven. After drying, the eyes and brain were separately extracted, ground, sieved and kept in freezer in McCartney bottles pending analysis. Five birds (all free range) were used in the study.

Crude protein determination and fat extraction. The micro-Kjeldahl method as described by Pearson (1976) was followed to determine the fat-free protein. The fat was extracted with a chloroform/methanol $(2: 1 \mathrm{v} / \mathrm{v})$ mixture using Soxhlet extraction apparatus (AOAC, 2006).

Amino acid analysis. Defatted samples between (30$35 \mathrm{mg}$ ) were weighed into glass ampoule, $7 \mathrm{~mL}$ of $6 \mathrm{MHCl}$ added and hydrolysed in an oven preset at $105 \pm 5^{\circ} \mathrm{C}$ for $22 \mathrm{~h}$. Oxygen was expelled in the ampoule by passing nitrogen gas into it. Amino acid analysis was done by ion-exchange chromatography (Moore et al., 1958) using a Technicon sequential multisample amino acid analyzer (Technicon Instruments Corporation, New York, USA). The period of analysis was $76 \mathrm{~min}$, with a gas flow rate of $0.50 \mathrm{~mL} / \mathrm{min}$ at $60{ }^{\circ} \mathrm{C}$, and the reproducibility was $\pm 3 \%$. Tryptophan was not determined due to cost. Norleucine was used as the internal standard.

Estimation of isoelectric point (pI). Theoretical estimation of isoelectric point ( $\mathrm{pI}$ ) was determined using the equation of Olaofe and Akintayo (2000) and information provided by Finar (1975).

Estimation of predicted protein efficiency ratio (P-PER). The predicted protein efficiency ratio (P-PER) was estimated by using the equation from Alsmeyer et al. (1974).

Estimation of dietary protein quality. The amino acid scores were calculated using three different procedures:

(i) scores based on amino acid values compared with whole hen's egg amino acid profile (Paul and Southgate, 1978);

(ii) scores based on essential amino acid scoring pattern (FAO/WHO, 1973);

(iii) scores based on essential amino acid suggested pattern of requirements for preschool child (FAO/WHO/UNU, 1985).

Estimation of amino acid index (EAAI). The essential amino acid index (EAAI) was determined by using the method of Steinke et al. (1980).

Leucine/Isoleucine ratio. The leucine/isoleucine ratios, their differences and their percentage differences were calculated.
Statistical analysis. Statistical analysis was carried out to determine the mean, standard deviation (SD) and the coefficients of variation percent ( $\mathrm{CV} \%$ ). A summary of the amino acids profile into factors $\mathrm{A}$ and $\mathrm{B}$ was also carried out (Oloyo, 2001).

\section{Results and Discussion}

Table 1 shows that amino acid of the eye was slightly concentrated (on pair wise comparisons) than the corresponding amino acid in the brain in 11/17 (64.7\%) (amino acid) or 12/18 (66.7\%) (amino acid plus protein) parameters, of the nine essential amino acids determined, $5 / 9$ or $55.6 \%$ were more concentrated in the eyes than the brain on pair wise comparisons. The most concentrated essential amino acid (EAA) in the samples was Leu $(7.02 \mathrm{~g} / 100 \mathrm{~g}$ (protein) in the brain and $6.02 \mathrm{~g} / 100 \mathrm{~g}$ (protein) in the eyes. The coefficient of variation per cent (CV \%) ranged between 3.32-15.8 in the amino acids, with Tyr having the least $\mathrm{CV} \%$ and Ala having the highest CV \%. From literature, the EAA with Cys and Tyr values had been given for the brain of cattle, pig and sheep (Fornias, 1996); in g/100 g protein. With these literature values, the present EAA results in the

Table 1. Amino acid composition (g/100 g protein) of the eyes and brain of Turkey-Hen (dry weight)

\begin{tabular}{|c|c|c|c|c|c|}
\hline Amino acid & Brain & Eyes & Mean* & SD & $\mathrm{CV} \%$ \\
\hline $\operatorname{Lys}^{\mathrm{a}}$ & 4.69 & 5.66 & 5.18 & 0.69 & 13.3 \\
\hline His $^{\mathrm{a}}$ & 1.85 & 2.14 & 2.00 & 0.21 & 10.3 \\
\hline $\mathrm{Arg}^{\mathrm{a}}$ & 4.49 & 5.18 & 4.84 & 0.49 & 10.1 \\
\hline Asp & 7.96 & 7.00 & 7.48 & 0.68 & 9.08 \\
\hline Thr $^{\mathrm{a}}$ & 4.01 & 3.41 & 3.71 & 0.42 & 11.4 \\
\hline Ser & 2.40 & 3.25 & 2.83 & 0.60 & 21.3 \\
\hline Glu & 11.3 & 12.8 & 12.1 & 1.06 & 8.80 \\
\hline Pro & 2.24 & 2.60 & 2.42 & 0.25 & 10.5 \\
\hline Gly & 4.66 & 3.81 & 4.24 & 0.60 & 14.2 \\
\hline Ala & 2.70 & 3.38 & 3.04 & 0.48 & 15.8 \\
\hline Met $^{\mathrm{a}}$ & 2.35 & 2.80 & 2.58 & 0.32 & 12.4 \\
\hline Cys & 0.71 & 0.79 & 0.75 & 0.06 & 7.54 \\
\hline $\mathrm{Val}^{\mathrm{a}}$ & 3.21 & 2.99 & 3.10 & 0.16 & 5.02 \\
\hline $\mathrm{Ile}^{\mathrm{a}}$ & 3.51 & 3.79 & 3.47 & 0.45 & 13.0 \\
\hline $\mathrm{Leu}^{\mathrm{a}}$ & 7.02 & 6.02 & 6.52 & 0.71 & 10.8 \\
\hline $\mathrm{Phe}^{\mathrm{a}}$ & 4.35 & 4.05 & 4.20 & 0.21 & 5.05 \\
\hline Tyr & 2.91 & 3.05 & 2.98 & 0.099 & 3.32 \\
\hline Try $^{\mathrm{a}}$ & - & - & - & - & - \\
\hline $\begin{array}{l}\text { Protein } \\
\text { (fat free) }\end{array}$ & 61.4 & 66.2 & 63.8 & 3.39 & 5.32 \\
\hline
\end{tabular}

$\bar{a}=$ essential amino acid; - = not determined; * = mean value is grand mean values of the amino acids; $\mathrm{SD}=$ standard deviation; $\mathrm{CV} \%=$ coefficient of variation per cent. 
brain can be described as follows: Leu (7.02), Ile (3.15), Lys (4.69), Met (2.35), Cys (0.71), Phe (4.35), Tyr 2.91), Thr (4.01), Val (3.21), His (1.85) and total (34.25). The value of $34.25 \mathrm{~g} / 100 \mathrm{~g}$ protein in the brain of Turkeyhen was close to the value of $34.81 \mathrm{~g} / 100 \mathrm{~g}$ protein in African giant pouch rat brain and $35.79 \mathrm{~g} / 100 \mathrm{~g}$ protein in the guinea fowl hen brain. In the eyes, the total EAA in the eyes of Turkey-hen was $34.7 \mathrm{~g} / 100 \mathrm{~g}$ protein, in the eyes of guinea fowl total was $36.62 \mathrm{~g} / 100 \mathrm{~g}$ and in the eyes of African giant pouch rat total was $35.31 \mathrm{~g} /$ $100 \mathrm{~g}$ protein. (Try was not determined in the present samples.)

The FAO/WHO/UNU (1985) standards for preschool children (2-5 years) were (g/100 g protein): Leu (6.6), Phe + Tyr (6.3), Thr (3.4), Try (1.1), Val (3.5), Ile (2.8), Lys (5.8), Met +Cys (2.5), His (1.9) and total (33.9 with His) and 32.0 (no His). Based on this information, the brain would provide enough or even more than enough of the Phe + Tyr, Ile, Leu, Thr, Met + Cys, His and total EAA while the eyes would provide enough or even more of Phe + Tyr, Thr, Ile, Met + Cys, His and total EAA. (Tryptophan was not determined.) Histidine is a semi-essential amino acid particularly useful for children growth. The value of Ile was 3.15-3.79 g/100 g protein in the samples. It is an essential amino acid for both old and young. Maple syrup urine disease is an inborn error of metabolism in which brain damage and early death can be avoided by a diet low in Ile and two other EAA, Leu and Val. Isoleucine was higher than the preschool standard (3.15-3.79 g/100 g protein versus $2.8 \mathrm{~g} / 100 \mathrm{~g}$ protein), Leu was lower in the eyes (6.02$7.02 \mathrm{~g} / 100 \mathrm{~g}$ protein versus $6.6 \mathrm{~g} / 100 \mathrm{~g}$ protein), whereas, Val was low in both samples $(2.99-3.21 \mathrm{~g} / 100 \mathrm{~g}$ protein versus $3.5 \mathrm{~g} / 100 \mathrm{~g}$ protein). Methionine is an EAA with value range of $2.35-2.80 \mathrm{~g} / 100 \mathrm{~g}$ protein in this report or 3.06-3.59 g/100 g protein with Cys. Methionine is needed for the synthesis of choline. Choline forms lecithin and other phospholipids in the body. When the diet is low in protein, for instance in alcoholism and kwashiorkor, insufficient choline may be formed; this may cause accumulation of fat in the liver (Bingham, 1977). Phenylalanine formed a value range of 4.05$4.35 \mathrm{~g} / 100 \mathrm{~g}$ protein in the samples. It is the precursor of some hormones and the pigment melanin in hair, eyes and tanned skin. In a normal diet, deficiency in Phe hardly occurs: for example, four large slices of bread supply the estimated adult needs for Phe and Tyr. Tyrosine is the precursor of some hormones (like the thyroid hormones) and the brown pigment melanin formed in hair, eyes and tanned skin. Tyrosine is found in all food proteins and reduces the requirement for Phe. Daily requirement of Phe is $31 \mathrm{mg} / \mathrm{kg}$ with a maintenance pattern of 4.3 (Rose, 1949). Tyrosine biosynthesis in mammals occurs by hydroxylation of Phe. Much of the dietary requirement for Phe is, in fact, due to the need for Tyr. If the latter is fed, the dietary requirement for Phe is reduced substantially. In this sense, Tyr bears the same relationship to Phe as cysteine does to Met. In normal metabolism, the only known fate of Phe, other than utilisation for protein synthesis, is its conversion to Tyr. The liver enzyme system catalysing this hydroxylation is Phenylalanine hydroxylase, a mixedfunction hydroxylase that utilises tetrahydrobiopterin as the reduced cofactor.

Problems could arise with addition of phenylalanine/ tyrosine in food. These include:

(i) Hereditary lack of Phe hydroxylase results in phenylketonuria. In the absence of this enzyme, minor pathways of Phe metabolism, little used in normal individuals, become prominent. Transamination from Phe yields phenylpyruvic acid, of which as much as 1-2 g/day may be excreted in the urine. The accumulation of phenylpyruvic acid also leads to formation and urinary excretion of Phenyllactic acid, o-hydroxyphenylacetic acid, and phenylacetic acid, the last as phenylacetylglutamine (White et al., 1973).

(ii) Phenylpyruvic acid is termed as keto acid because of its molecular structure; hence, the disease is known as phenylketonuria or PKU. People with the disease are called phenylketonurics. Infants diagnosed PKU must be put on a diet severely limited in Phe, avoiding excess Phe from milk, meats, other sources of rich protein. Phenylalanine is an EAA, a minimum amount of it must be available. Supplemented Tyr may also be needed to compensate for the absence of the normal conversion of Phe to Tyr (Eubanks et al., 2009).

(iii) High levels of tyrosine. Due to a temporary insufficiency of an enzyme necessary for its normal metabolismsometimes it accumulates in the blood stream of babies. Permanent deficiency of the enzyme-hypertyrosinaemia, a rare inborn error of metabolism- can cause liver and kidney failure unless treated with a synthetic diet low in Phe and Tyr. Food containing tyramine, a derivative of tyrosine, must be avoided when certain tranquillisers are taken. Tyramine occurs naturally in cheese, extracts, baked beans, alcohol and yogurt. It is normally detoxicated by a group of enzymes called the monoamine oxidases 
(MAO), but certain antidepressant drugs inhibit their action. These foods must not be eaten in conjunction with MAO inhibiting drugs: an alarming rise in blood pressure with sometimes fatal result has been recorded (Bingham, 1977). Valine, an EAA is restricted in the treatment of maple syrup urine disease.

Table 2 presents parameters on the quality of the protein of the samples. The EAA ranged between 35.1$36.0 \mathrm{~g} / 100 \mathrm{~g}$ protein of the samples with a variation of $0.43 \%$ (least $\mathrm{CV} \%$ ). These values were more than half the average of $56.6 \mathrm{~g} / 100 \mathrm{~g}$ protein of the egg reference protein (Paul and Southgate, 1978). The total sulphur amino acid (TSAA) of the samples was $3.06 \mathrm{~g} / 100 \mathrm{~g}$ protein (brain) and $3.59 \mathrm{~g} / 100 \mathrm{~g}$ protein (eyes). The values of $3.06-3.59 \mathrm{~g} / 100 \mathrm{~g}$ protein were close to the value of $5.8 \mathrm{~g} / 100 \mathrm{~g}$ protein recommended for infants (FAO/ WHO/UNU, 1985). The aromatic amino acid (ArAA)

Table 2. EAA, non-EAA, acidic, neutral, sulphur and aromatic amino acid contents ( $\mathrm{g} / 100 \mathrm{~g}$ protein) of the eyes and brain of Turkey-hen (dry weight)

\begin{tabular}{|c|c|c|c|c|c|}
\hline Amino acid & Brain & Eyes & Mean & SD & $\mathrm{CV} \%$ \\
\hline $\begin{array}{l}\text { Total amino } \\
\text { acids (TAA) }\end{array}$ & 70.5 & 72.7 & 71.6 & 1.56 & 2.17 \\
\hline $\begin{array}{l}\text { Total non-essential } \\
\text { amino acid (TNEAA) }\end{array}$ & 35.4 & 36.7 & 36.1 & 0.92 & 2.55 \\
\hline \multicolumn{6}{|l|}{ Total EAA } \\
\hline -with His & 35.1 & 36.0 & 35.6 & 0.64 & 1.79 \\
\hline -no His & 33.3 & 33.9 & 3.36 & 0.42 & 12.6 \\
\hline$\%$ TNEAA & 50.2 & 50.5 & 50.4 & 0.21 & 0.42 \\
\hline \multicolumn{6}{|l|}{$\%$ Total EAA } \\
\hline -with His & 49.8 & 49.5 & 49.7 & 0.21 & 0.43 \\
\hline -no His & 47.2 & 46.6 & 46.9 & 0.42 & 0.90 \\
\hline $\begin{array}{l}\text { Total neutral } \\
\text { amino acid (TNAA) }\end{array}$ & 39.7 & 39.9 & 39.8 & 0.14 & 0.36 \\
\hline$\%$ TNAA & 56.3 & 54.9 & 55.6 & 0.99 & 1.78 \\
\hline $\begin{array}{l}\text { Total acidic } \\
\text { amino acid (TAAA) }\end{array}$ & 19.3 & 19.8 & 19.6 & 0.35 & 1.81 \\
\hline$\%$ TAAA & 27.4 & 27.2 & 27.3 & 0.14 & 0.52 \\
\hline $\begin{array}{l}\text { Total basic } \\
\text { amino acid (TBAA) }\end{array}$ & 11.0 & 13.0 & 12.0 & 1.41 & 11.8 \\
\hline$\%$ TBAA & 15.6 & 17.9 & 16.8 & 1.63 & 9.71 \\
\hline $\begin{array}{l}\text { Total sulphur } \\
\text { amino acid (TSAA) }\end{array}$ & 3.06 & 3.59 & 3.33 & 0.37 & 11.3 \\
\hline$\%$ TSAA & 4.34 & 4.94 & 4.64 & 0.42 & 9.14 \\
\hline$\%$ Cys in TSAA & 23.2 & 22.0 & 22.6 & 0.85 & 3.75 \\
\hline $\begin{array}{l}\text { Total aromatic } \\
\text { amino acid (TArAA) }\end{array}$ & 9.11 & 9.24 & 9.18 & 0.09 & 1.00 \\
\hline$\%$ TArAA & 12.9 & 12.7 & 12.8 & 0.14 & 1.10 \\
\hline
\end{tabular}

range suggested for infant protein (6.8-11.8 g/100 g protein) (FAO/WHO/UNU, 1985) was very favourably comparable with current report of 9.11-9.24 g/100 g protein showing that the samples protein could be used to supplement sorghum flour (Adeyeye, 2008a), whole wheat flour (Adeyeye, 2011b) and pearl millet (Adeyeye, $2009 \mathrm{~b})$. The TSAA of the eyes and brain of African giant pouch rat ranged as 3.61-3.62 g/100 g protein, whilst the ArAA ranged as 7.45-7.87 g/100 g protein (Oyarekua and Adeyeye, 2011), whereas, the corresponding values in the brains and eyes of guinea fowl were 3.15-3.47 g/100 g protein (TSAA) and 7.32-8.93 g/100 g protein, respectively (Adeyeye and Aremu, 2010). The percentage ratio of EAA to the total amino acid (TAA) in the samples ranged between 49.5-49.8\%. These values were well above the $39 \%$ considered adequate for ideal protein food for infants, $26 \%$ for children and $11 \%$ for adults (FAO/WHO/UNU, 1985).

The percentage of EAA/TAA for the samples could be favourably compared with other animal protein sources: 46.2\% in Zonocerus variegatus (Adeyeye, 2005a), 43.7\% in Macrotermes bellicosus (Adeyeye, 2005b), $54.8 \%$ in Gymnarchus niloticus (Trunk fish) (Adeyeye and Adamu, 2005), 48.1-49.9\% in brain and eyes (African giant pouch rat) and in the brain and eyes of guinea fowl, $47.5-52.2 \%$, whereas, it is $50 \%$ for egg (FAO/WHO, 1990). The total EAA in these results were close to the value of $44.4 \mathrm{~g} / 100 \mathrm{~g}$ protein in soybean (Yuwai et al., 1991), melon and gourd oilseeds with respective values of $53.4 \mathrm{~g} / 100 \mathrm{~g}$ protein (Olaofe et al., 1994). The percentage of total neutral amino acid (TNAA) ranged from 54.9-56.3, indicating that they formed the bulk of the amino acids; total acidic amino acid (TAAA) ranged from 27.2-27.4\% which were far lower than \% TNAA, whilst the percentage range in total basic amino acid (TBAA) was 15.6-17.9, which made them the third largest group among the samples.

Most animal proteins are low in Cys, for examples: $36.3 \%$ in M. bellicosus (Adeyeye, 2005b); 25.6\% in Z. variegatus (Adeyeye, 2005a); 35.5\% in Archachatina marginata, 38.8\% in Archatina archatina and 21.0\% in Limicolaria sp., respectively (Adeyeye and Afolabi, 2004); 23.8-30.1\% in three different Nigerian fishes (Adeyeye, 2009c); 27.3-32.8\% in female fresh water crab body parts (Adeyeye, 2008b); 13.3-15.9\% in male fresh water crab body parts (Adeyeye and Kenni, 2008); 26.0-26.5\% in Turkey-hen meat (Adeyeye and Ayejuyo, 2007) in their (Cys/TSAA) \% values. The present results corroborated these observations with values of 23.2 
(brain) down to $22.0 \%$ (eyes). In other brain/eyes (Cys/TSAA) \% values, it was 34.6 (brain) down to 20.6\% (eyes) in guinea fowl (Adeyeye and Aremu, 2010 ) and also 28.2 (brain) down to $20.8 \%$ (brain) in African giant pouch rat (Oyarekua and Adeyeye, 2011). In contrast, many vegetable proteins contain substantially more Cys than Met, examples (Cys/TSAA) \%: 62.9\% in coconut endosperm (Adeyeye, 2004); in Anacardium occidentale it is $50.5 \%$ (Adeyeye et al., 2007); 58.9-72.0 in sorghum (raw, steeped, germinated) (Adeyeye, 2008a); 45.8-52.6 (raw, steeped, germinated) wheat (Adeyeye, 2011b); 51.2-53.1 (raw, steeped, germinated) pearl millet (Adeyeye, 2009b). Thus, for animal protein diets or mixed diets containing animal protein, Cys is unlikely to contribute up to $50 \%$ of the TSAA (FAO/ WHO, 1991). The percentage of Cys in TSAA had been set at $50 \%$ in rat, chick and pig diets (FAO/WHO, 1991). Cys can spare with Met in improving protein quality and has positive effects on mineral absorption, particularly zinc (Mendoza, 2002; Sandstrom et al., 1989).

The data in Table 3 depicted the differences in the amino acid concentration values ( $\mathrm{g} / 100 \mathrm{~g}$ protein) between the brain and the eyes. Values in Lys, His, Arg, Ser, Glu, Pro, Gly, Ala, Met, Cys, Ile, Tyr and protein were more concentrated in the eyes than in the brain; this gave a value of $12 / 18$ or $66.7 \%$. Among the essential amino acids, $5 / 9$ or $55.6 \%$ members were more positively concentrated in the eyes than the brain. For all the amino acids, where values in eyes were better than the brain, better concentrated values were in the percentage range of 4.81-35.4\%; on the EAA side, range was $6.90-20.7 \%$.

In Table 4, some specialised amino acid quality parameters in the samples were shown. The $\mathrm{CV} \%$ values were generally higher than in Tables 1 and 2; they ranged from 1.32-38.0. In all the parameters reported, the brain was higher in predicted protein efficiency ratio (P-PER), Leu/Ile ratio, Leu-Ile (difference) and \% Leu-Ile (difference), whereas, eyes had higher values in essential amino acid index (EAAI) and the isoelectric point (pI). The predicted protein efficiency ratio (P-PER) was 2.41 (brain) and 1.94 (eyes). These results were highly comparable to the following literature values: 2.27 (skin) and 1.93 (muscle) of Turkey-hen (Adeyeye and Ayejuyo, 2007); it is 2.22 (Clarias anguillaris), 1.92 (Oreochromis niloticus) and 1.89 (Cynoglossus senegalensis) (Adeyeye, 2009c); 1.82 (brain) and 2.33 (eyes) of guinea fowl (Adeyeye and Aremu, 2010); 1.58 (brain) and 2.08 (eyes) of African giant pouch rat (Oyarekua and Adeyeye, 2011) but lower than in the values from various parts of fresh
Table 3. Differences (g/100 g protein) between the amino acids composition of the eyes and brain of Turkey-hen (dry weight)

\begin{tabular}{llll}
\hline \hline Amino acid & Brain & Eyes & Difference* \\
\hline Lys & 4.69 & 5.66 & $-0.97(20.7 \%)$ \\
His & 1.85 & 2.14 & $-0.29(15.7 \%)$ \\
Arg & 4.49 & 5.18 & $-0.69(15.4 \%)$ \\
Asp & 7.96 & 7.00 & $+0.96(12.1 \%)$ \\
Thr & 4.01 & 3.41 & $+0.60(15.0 \%)$ \\
Ser & 2.40 & 3.25 & $-0.85(35.4 \%)$ \\
Glu & 11.3 & 12.8 & $-1.50(13.3 \%)$ \\
Pro & 2.24 & 2.60 & $-0.36(16.1 \%)$ \\
Gly & 4.66 & 3.81 & $+0.85(18.2 \%)$ \\
Ala & 2.70 & 3.38 & $-0.68(25.2 \%)$ \\
Met & 2.35 & 2.80 & $-0.45(19.1 \%)$ \\
Cys & 0.71 & 0.79 & $-0.08(11.3 \%)$ \\
Val & 3.21 & 2.99 & $+0.22(6.85 \%)$ \\
Ile & 3.15 & 3.79 & $-0.64(20.3)$ \\
Leu & 7.02 & 6.02 & $+1.00(14.2 \%)$ \\
Phe & 4.35 & 4.05 & $+0.3(6.90 \%)$ \\
Tyr & 2.91 & 3.05 & $-0.14(4.81 \%)$ \\
Try & - & - & - \\
Protein & 61.4 & 66.2 & $-4.8(7.82 \%)$ \\
\hline \hline
\end{tabular}

$*$ = negative values mean amino acid value in eye is higher than in the brain and vice versa for the positive sign; same sign runs before and within the brackets.

Table 4. Some specialized amino acid quality parameters in the samples

\begin{tabular}{lccccc}
\hline \hline Parameter & Brain & Eyes & Mean & SD & CV \% \\
\hline P-PER & 2.41 & 1.94 & 2.18 & 0.33 & 15.3 \\
Leu/Ile ratio & 2.23 & 1.59 & 1.91 & 0.45 & 23.7 \\
Leu-Ile (difference) & 3.87 & 2.23 & 3.05 & 1.16 & 38.0 \\
\% Leu-Ile (difference) & 55.1 & 37.0 & 46.1 & 12.8 & 27.8 \\
EAAI & 1.06 & 1.08 & 1.07 & 0.01 & 1.32 \\
Isoelectric point (pI) & 3.97 & 4.18 & 4.08 & 0.15 & 3.64 \\
\hline \hline
\end{tabular}

water female crab: 3.4 (whole body), 3.1 (flesh), 2.6 (exoskeleton) (Adeyeye, 2008b); fresh male crab: 2.9 (whole body), 2.8 (flesh), 2.4 (exoskeleton) (Adeyeye and Kenni, 2008); 4.06 (corn ogi) and reference casein with PER of 2.50 (Oyarekua and Eleyinmi, 2004); 2.56 (cattle brain), 3.04 (pig brain) and 2.68 (sheep brain) (Fornias, 1996). Other literature values were 1.21 (cowpea), 1.82 (pigeon pea) (Salunkhe and Kadam, 1989); 1.62 (millet ogi) and 0.27 (sorghum ogi) (Oyarekua and Eleyinmi, 2004); greater than 0.00 (raw sorghum), 0.23 (steeped sorghum) and 0.29 (germinated sorghum) (Adeyeye, 2008a). The Leu/Ile ratio was low in both 
samples (1.59-2.23) with CV \% of 23.7, hence, no concentration antagonism might be experienced in the Turkey-hen samples when used as protein source in food. The essential amino acid index (EAAI) ranged from 1.06 (brain) -1.08(eyes) and CV \% of 1.32. EAAI is useful as a rapid tool to evaluate food formulations for protein quality, although it does not account for differences in protein quality due to various processing methods or certain chemical reactions (Nielsen, 2002). The EAAI of defatted soybean is 1.26 (Nielsen, 2002); this is a bit higher than the present results. In the results of the isoelectric points (pI), there was a shift from 3.97 (brain) up to 4.18 (eyes). This type of shift was also seen in turkey meat: from 4.41 (skin) to 5.01 (muscle) (Adeyeye and Ayejuyo, 2007); from 4.64 (brain) down to 4.32 (eyes) in guinea fowl (Adeyeye and Aremu, 2010); 4.28 (brain) down to 4.25 (eyes) in African giant pouch rat (Oyarekua and Adeyeye, 2011). The calculation of $\mathrm{pI}$ from amino acids would assist in the production of the protein isolate of organic product without going through the process of determining the functionality of the organic product.

Table 5 shows the amino acid scores (AAS) of the samples based on whole hen's egg profile (Paul and Southgate, 1978). The score values were very close with the variation ranging from $2.85-21.9 \%$. The least or limiting amino acid score was Ser in both samples with values as 0.30 (brain) and 0.41 (eyes) but highest variation of $21.9 \%$. The Turkey-hen head organs (brain and eyes) generally showed good comparisons with the amino acid profile of the whole hen's egg. The highest score in the samples was glycine (1.27-1.55) and CV \% of 14.0. The highest EAA score in the brain was shared between Phe and Leu, each having a score of 0.85 but different CV \% with 5.17 (Phe) and 10.7 (Leu). The highest EAA score in the eyes was Lys (0.91). The least score in the two samples was Ser with values of $0.30-0.41$ with CV \% value of 21.9 (being the highest CV \%).

Table 6 depicts the essential amino acid scores (EAAS) based on the provisional amino acid scoring pattern (FAO/WHO, 1973). The EAAS greater than 1.00 or equal to 1.00 in the brain were Thr, Leu and Phe $+\mathrm{Tyr}$ whereas they were Met + Cys, Lys and Phe + Tyr in the eyes. The limiting amino acid (LAA) in the brain was Val (0.64) whereas it was also Val in the eyes $(0.60)$. Although this would have been described as the LAA, however, the EAA most often acting in a limiting capacity are methionine (and cysteine), lysine, threonine and tryptophan (FAO/WHO/UNU, 1985). Since Try
Table 5. Amino acid scores of the Turkey-hen head organs based on whole hen's amino acid profile

\begin{tabular}{llllll}
\hline \hline Amino acid & Brain & Eyes & Mean & SD & CV \% \\
\hline Lys & 0.76 & 0.91 & 0.84 & 0.11 & 12.7 \\
His & 0.77 & 0.89 & 0.83 & 0.08 & 10.2 \\
Arg & 0.74 & 0.85 & 0.80 & 0.08 & 9.78 \\
Asp & 0.74 & 0.65 & 0.70 & 0.06 & 9.16 \\
Thr & 0.79 & 0.67 & 0.73 & 0.08 & 11.6 \\
Ser & 0.30 & 0.41 & 0.36 & 0.08 & 21.9 \\
Glu & 0.94 & 1.07 & 1.01 & 0.09 & 9.15 \\
Pro & 0.59 & 0.68 & 0.64 & 0.06 & 10.0 \\
Gly & 1.55 & 1.27 & 1.41 & 0.20 & 14.0 \\
Ala & 0.50 & 0.63 & 0.57 & 0.09 & 16.3 \\
Cys & 0.39 & 0.44 & 0.42 & 0.04 & 8.52 \\
Val & 0.43 & 0.40 & 0.42 & 0.02 & 5.11 \\
Met & 0.73 & 0.88 & 0.81 & 0.11 & 13.2 \\
Ile & 0.56 & 0.68 & 0.62 & 0.08 & 12.5 \\
Leu & 0.85 & 0.73 & 0.79 & 0.08 & 10.7 \\
Tyr & 0.73 & 0.76 & 0.75 & 0.02 & 2.85 \\
Phe & 0.85 & 0.79 & 0.82 & 0.04 & 5.17 \\
Total & 0.71 & 0.74 & 0.73 & 0.02 & 2.93 \\
\hline \hline
\end{tabular}

Table 6. Amino acid scores of the Turkey-hen eyes and brain based on the provisional essential amino acid scoring pattern

\begin{tabular}{llllll}
\hline \hline Amino acid & Brain & Eyes & Mean & SD & CV \% \\
\hline Lys & 0.85 & 1.03 & 0.94 & 0.13 & 13.5 \\
Thr & 1.00 & 0.85 & 0.93 & 0.11 & 11.5 \\
Met + Cys & 0.87 & 1.03 & 0.95 & 0.11 & 11.9 \\
Val & 0.64 & 0.60 & 0.62 & 0.03 & 4.56 \\
Ile & 0.79 & 0.95 & 0.87 & 0.11 & 13.0 \\
Leu & 1.00 & 0.86 & 0.93 & 0.10 & 10.6 \\
Phe + Tyr & 1.21 & 1.18 & 1.20 & 0.02 & 1.78 \\
Try & - & - & - & - & - \\
Total & 0.93 & 0.93 & 0.93 & 0.00 & - \\
\hline \hline
\end{tabular}

was not determined, Thr would be limiting in the eyes (0.85). (Just as in the eyes of guinea fowl, where Thr was also limiting at 0.85 .) To make corrections for LAA in the eyes if they serve as sole sources of protein food therefore, it would be $100 / 85.0 \times$ protein of eyes; or $1.18 \times$ protein of eyes. The highest EAAS in the brain was Phe $+\operatorname{Tyr}(1.21)$ and also Phe $+\operatorname{Tyr}(1.18)$ in the eyes. The $\mathrm{CV} \%$ values were generally close ranging between 1.78 and 13.5.

Table 7 presents the EAAS based on suggested requirement of the EAA of a preschool child (FAO/ WHO/ UNU, 1985). Greater numbers of scores were $>1.00$ than as seen in Table 6. Here, in the brain, Thr, Met + 
Cys, Ile, Leu, Phe + Tyr and total (essential amino acids) had scores $>1.00$ each; whereas in the eyes, His, Thr, Met + Cys, Ile, Phe + Tyr and total had scores $\geq 1.00$ each. The CV \% had similar scores as found in Table 6 having values of 1.24-13.4.

Table 7. Amino acid scores of the Turkey-hen eyes and brain based on the suggested requirement of the essential amino acid of preschool child

\begin{tabular}{llllll}
\hline \hline Amino acid & Brain & Eyes & Mean & SD & CV\% \\
\hline Lys & 0.81 & 0.98 & 0.90 & 0.12 & 13.4 \\
His & 0.97 & 1.13 & 1.05 & 0.11 & 10.8 \\
Thr & 1.18 & 1.00 & 1.09 & 0.13 & 11.7 \\
Val & 0.92 & 0.85 & 0.89 & 0.05 & 5.59 \\
Met + Cys & 1.22 & 1.44 & 1.33 & 0.16 & 11.7 \\
Ile & 1.13 & 1.35 & 1.24 & 0.16 & 12.5 \\
Leu & 1.06 & 0.91 & 0.99 & 0.11 & 10.8 \\
Phe + Tyr & 1.15 & 1.13 & 1.14 & 0.01 & 1.24 \\
Try & - & - & - & - & - \\
Total & 1.04 & 1.06 & 1.05 & 0.01 & 1.35 \\
\hline \hline
\end{tabular}

Three different amino acid scores each had their scores less than 1.00 in the samples: for the brain we have Lys (0.81), His (0.97) and Val (0.92); for the eyes we have Lys (0.98), Val (0.85) and Leu (0.91). The highest score in the samples came from Met + Cys with values of 1.22 (brain) and 1.44 (eyes) and CV \% of 11.7; in Table 6 , Phe + Tyr had the highest scores in both samples: 1.21 (brain) and 1.18 (eyes) and CV \% of 1.78. The recognized limiting amino acid in both samples was Lys with values of 0.81 (brain) and 0.98 (eyes) with respective corrections of 100/81.0 (1.23) $\times$ protein of brain and 100/98.0 $(1.02) \times$ protein of eyes.

The following values would show the position of the quality of the Turkey-hen brain and eyes protein: the EAA requirements across board are (values with His) (g/100 g protein): infant (46.0), preschool (2-5 years) (33.9), school child (10-12 years) (24.1) and adult (12.7) and without His: infant (43.4), preschool (32.0), school child (22.2) and adult (11.1) (FAO/WHO/UNU, 1985); from the present results based on these standards, $34.3 \mathrm{~g}$ protein (with His) and 32.4 (no His) in brain; $34.7 \mathrm{~g}$ protein (with His) and $32.6 \mathrm{~g}$ protein (no His) in eyes have been observed. While the present results would satisfy a high percentage of infant needs, they will satisfy the requirements of preschool children and above.
Table 8 reveals a brief summary of the amino acid profiles in two samples. Column (under Factor B means) shows that the values were very close with a range of 35.7-35.9 g/100 g protein. It is to be noted that both Factor A means and Factor B means terminated at a similar value of $35.8 \mathrm{~g} / 100 \mathrm{~g}$ protein.

Table 8. Summary of the amino acid profiles into factors $\mathrm{A}$ and $\mathrm{B}$ means ( $\mathrm{g} / 100 \mathrm{~g}$ protein)

\begin{tabular}{llcl}
\hline \hline $\begin{array}{l}\text { Amino acid } \\
\text { composition (Factor B) }\end{array}$ & Samples (Factor A) & \\
\cline { 2 - 3 } & Brain & Eyes & $\begin{array}{l}\text { Factor B } \\
\text { means }\end{array}$ \\
\hline $\begin{array}{l}\text { Total essential } \\
\text { amino acid }\end{array}$ & 35.1 & 36.7 & 35.9 \\
$\begin{array}{l}\text { Total non-essential } \\
\text { amino acid }\end{array}$ & 35.4 & 36.0 & 35.7 \\
\hline Factor A means & 35.25 & 36.35 & 35.8 \\
\hline \hline
\end{tabular}

The statistical analysis of the data in Tables 1, 4 (pI only), 5, 6 and 7 was shown in Table 9. The correlation coefficient was positively high and significant at $\mathrm{r} 0.01$ in data from Table 1 and 4 (pI only) and 5 but positively high but not significant at $r_{0.01}$ in the data from Table 6 and 7. This similar trend was observed in the coefficient of determination $\left(\mathrm{r}_{\mathrm{xy}}{ }^{2}\right)$ although with much lower values in data from Table 6 and 7. The regression coefficient $\left(\mathrm{R}_{\mathrm{xy}}\right)$ was generally low but positive from values in Tables 1, 4, 5, 6 and 7. The general mean was calculated for each Table but it was interesting to note that the $\mathrm{CV} \%$ started to decrease as one moved from Table 1, $4,5,6,7$; in the brain, it was Table: $1(62.9 \%)>4$ $(53.8 \%)>5(38.7 \%)>6(20.0 \%)>7(13.5 \%)$ and in the eyes: $1(62.4 \%)>4(52.1 \%)>5(30.3 \%)>6(19.8 \%)$ $>7(18.9 \%)$. The coefficient of alienation $\left(\mathrm{C}_{\mathrm{A}}\right)$ was low from Table 1, 4 and 5 (range of value $=0.2717-0.4398$ ) but high from Table 6 and 7 (range of value $=0.7258$ 0.8001 ). The values of index of forecasting efficiency (IFE) were in the reverse order from the $\mathrm{C}_{\mathrm{A}}$; this is the expected since both $\mathrm{C}_{\mathrm{A}}+\mathrm{IFE}=1.00$ in each case of appearance. The $\mathrm{r}_{\mathrm{xy}}$ value was highest in 1 and 4 at $\mathrm{r}_{0.01}$ and $n-2$ degrees of freedom. The regression coefficient $\left(R_{x y}\right)$ showed that for every unit increase in the brain amino acid parameter, the increase in the eyes was 0.1940 (Table 1), 0.1190 (Table 4), 0.2224 (Table 5), 0.2967 (Table 6) and 0.1777 (Table 7). The variance $\left(\mathrm{r}_{\mathrm{xy}}{ }^{2}\right)$ followed the pattern as seen in the $\mathrm{r}_{\mathrm{xy}}$ with value trend as shown: Table $1\left(\mathrm{r}_{\mathrm{xy}}{ }^{2}\right)>$ Table $4>$ Table $5>$ Table $6>$ Table 7 . The grand mean, standard deviation 
Table 9. Summary of the statistical analysis of the data in Tables 1, 4, 5, 6 and 7

\begin{tabular}{llllll}
\hline \hline Parameter & \multicolumn{5}{c}{ Sources of statistics (from Tables) } \\
\cline { 2 - 6 } & 1 & 4 & 5 & 6 & 7 \\
\hline $\begin{array}{l}\text { Correlation } \\
\text { coefficient }\left(\mathrm{r}_{\mathrm{xy}}\right)\end{array}$ & $0.9624^{*}$ & $0.9523^{*}$ & $0.8981^{*}$ & 0.6879 & 0.5999 \\
$\begin{array}{l}\text { Coefficient of } \\
\text { determination }\left(\mathrm{r}_{\mathrm{xy}}{ }^{2}\right)\end{array}$ & 0.9262 & 0.9069 & 0.8066 & 0.4732 & 0.3599 \\
$\begin{array}{l}\text { Regression } \\
\text { coefficient }\left(\mathrm{R}_{\mathrm{xy}}\right)\end{array}$ & 0.1940 & 0.1190 & 0.2224 & 0.2967 & 0.1777 \\
$\begin{array}{l}\text { Mean (brain }=\mathrm{A}) \\
\text { SD (A) }\end{array}$ & 4.12 & 23.4 & 0.7188 & 0.9086 & 1.055 \\
CV \% (A) & 2.59 & 12.6 & 0.2785 & 0.1820 & 0.1429 \\
$\begin{array}{l}\text { Mean (eyes = B) } \\
\text { SD (B) }\end{array}$ & 4.28 & 24.6 & 0.7476 & 0.9286 & 1.0988 \\
CV \% (B) & 2.67 & 12.8 & 0.2266 & 0.1840 & 0.2080 \\
$\begin{array}{l}\text { Coefficient of } \\
\text { alienation (C }\end{array}$ & 0.2717 & 0.3051 & 0.4398 & 0.7258 & 0.8001 \\
$\begin{array}{l}\text { Index of forecasting } \\
\text { efficiency (IFE) }\end{array}$ & 0.7283 & 0.6949 & 0.5602 & 0.2742 & 0.1999 \\
\hline
\end{tabular}

* $=\mathrm{r}_{\mathrm{xy}}$ significant at $\mathrm{r}_{\mathrm{xy}}=0.066$ at $\alpha=0.01$ and $\mathrm{n}-2(15) \mathrm{df}$.

and $\mathrm{CV} \%$ for all the amino acids in each of the samples could be seen in Table 9; it covered all the values from Table 1, 4, 5, 6 and 7. The overall amino acids from Table 1 gave mean values of brain/eyes as 4.12-4.2 $\mathrm{g} / 100 \mathrm{~g}$ protein, $\mathrm{SD}$ as $2.59-2.67, \mathrm{CV} \%$ as 62.9-62.4; etc.

The coefficient of alienation $\left(\mathrm{C}_{\mathrm{A}}\right)$ was low in Table 1 $(0.27$ or $27 \%)$, Table $4(0.31$ or $31 \%)$ and Table $5(0.44$ or $44 \%)$ but high in Table $6(0.73$ or $73 \%)$ and Table 7 $(0.80$ or $80 \%)$. The index of forecasting efficiency (IFE) was high in Table 1 ( 0.73 or $73 \%)$, Table 4 ( 0.69 or $69 \%)$ and Table $5(0.56$ or $56 \%)$, while others were low at 27-20\% (Table 6 and 7, respectively). Low IFE versus high $\mathrm{C}_{\mathrm{A}}$ makes prediction of relationship difficult. The $\mathrm{C}_{\mathrm{A}}$ produces an index of lack of relationship while the IFE gives the reduction in the errors of prediction of relationship. The $\mathrm{C}_{\mathrm{A}}$ and IFE values showed that a good relationship existed between the brain and eyes amino acid in turkey particularly with the results in Table 1, 4 and 5. High values of the IFE showed that the physiological activities of the brain could be carried out by the eyes and vice versa. The pattern of $\mathrm{r}_{\mathrm{xy}}$ results from Table 1 and 2 were similar to those obtained for the amino acid profiles of the shell and flesh of Penaeus notabilis (Adeyeye et al., 2008); results in the Table 1, 4 and 5 were in agreement with the results in Tables 1, 2 and 4 in the brain and eyes of guinea fowl (Adeyeye and Aremu, 2010); similar results also came from the eyes and brain of the African giant pouch rat (Oyarekua and Adeyeye, 2011).

The comparison of the amino acids profile in the eyes and brain of Turkey-hen and the amino acid profiles on the eyes and brain of guinea-fowl hen could be seen in Table 10. The values of the organs in the two bird samples were highly comparable.

Table 10. Amino acid composition of the eyes and brain of Turkey-hen and Guinea fowl hen compared (g/100 g)

\begin{tabular}{|c|c|c|c|c|}
\hline \multirow[t]{2}{*}{ Amino acid } & \multicolumn{2}{|c|}{ Brain } & \multicolumn{2}{|l|}{ Eyes } \\
\hline & Guinea fowl & Turkey & Guinea fowl & Turkey \\
\hline Lys & 5.04 & 4.69 & 5.51 & 5.18 \\
\hline His & 3.03 & 1.85 & 2.50 & 2.14 \\
\hline Arg & 7.10 & 4.49 & 4.75 & 5.18 \\
\hline Asp & 9.96 & 7.96 & 7.00 & 7.00 \\
\hline Thr & 3.20 & 4.01 & 3.40 & 3.41 \\
\hline Ser & 2.26 & 2.40 & 3.16 & 3.25 \\
\hline Glu & 14.0 & 11.3 & 14.2 & 12.8 \\
\hline Pro & 3.93 & 2.24 & 3.00 & 2.60 \\
\hline Gly & 3.26 & 4.66 & 3.60 & 3.81 \\
\hline Ala & 4.50 & 2.70 & 3.69 & 3.38 \\
\hline Met & 2.27 & 2.35 & 2.50 & 2.80 \\
\hline Cys & 1.20 & 0.71 & 0.65 & 0.79 \\
\hline Val & 3.06 & 3.21 & 4.10 & 2.99 \\
\hline Ile & 3.26 & 3.15 & 3.74 & 3.79 \\
\hline Leu & 5.80 & 7.02 & 6.90 & 6.02 \\
\hline Phe & 5.60 & 4.35 & 4.12 & 4.05 \\
\hline Tyr & 3.33 & 2.91 & 3.20 & 3.05 \\
\hline Try & - & - & - & - \\
\hline $\begin{array}{l}\text { Protein } \\
\text { (Fat free) }\end{array}$ & 60.7 & 61.4 & 64.4 & 66.2 \\
\hline
\end{tabular}

\section{Conclusion}

This study had presented the amino acid data of the head organs (brain and eyes) of Turkey (Meleagris gallopavo L.) hen. It was found that the samples were good sources of high quality protein of almost adequate or more than adequate of essential amino acids, low Leu/Ile ratio and high protein efficiency ratio values thereby providing a probable premium quality meat.

\section{References}

Adeyeye, E.I. 2013. The comparison of the amino acids profiles of whole eggs of duck, francolin and Turkey consumed in Nigeria. Global Journal of Science Frontier Research B, 13: 10-20.

Adeyeye, E.I. 2012. Amino acids profile of the organ 
meats of the Turkey-hen (Meleagris gallopavo). Research and Reviews: Journal of Food and Dairy Technology, 1: 1-8.

Adeyeye, E.I. 2011a. Effect of salts on the food properties of Turkey hen (Melagris gallopavo L.) muscle flour. International Journal of Chemical Sciences, 4: 271-282.

Adeyeye, E.I. 2011b. Relationship in amino acid quality between raw, steeped and germinated wheat (Triticum durum) grains. Bangladesh Journal of Scientific and Industrial Research, 46: 89-100.

Adeyeye, E.I., Aremu, M.O. 2010. Comparative evaluation of the amino acid profile of the brain and eyes of guinea fowl (Numida meleagris) hen. The Open Nutraceutical Journal, 3: 220-226.

Adeyeye, E.I. 2009a. Comparative study on the characteristics of egg shells of some bird species. Bulletin of the Chemical Society of Ethiopia, 23: 159-166.

Adeyeye, E.I. 2009b. The intercorrelation of the amino acid quality between raw, steeped and germinated pearl millet (Pennisetum typhoides) grains. Pakistan Journal of Scientific and Industrial Research, 52: 122-129.

Adeyeye, E.I. 2009c. Amino acid composition of three species of Nigerian fish: Clarias anguillaris, Oreochromis niloticus and Cynoglossus senegalensis. Food Chemistry, 113: 43-46.

Adeyeye, E.I., Kenni, A.M. 2008. The relationship in the amino acid of the whole body, flesh and exoskeleton of common west African fresh water male crab Sudananautes africanus africanus. Pakistan Journal of Nutrition, 7: 748-752.

Adeyeye, E.I., Adubiaro, H.O. Awodola, O.J. 2008. Comparability of chemical composition and functional properties of shell and flesh of Penaeus notabilis. Pakistan Journal of Nutrition, 7: 741-747.

Adeyeye, E.I. 2008a. The intercorrelation of the amino acid quality between raw, steeped and germinated guinea corn (Sorghum bicolor) grains. Bulletin of the Chemical Society of Ethiopia, 22: 11-17.

Adeyeye, E.I. 2008b. Amino acid composition of the whole body, flesh and exoskeleton of female common West African fresh water crab Sudananautes africanus africanus. International Journal of Food Sciences and Nutrition, 59: 699-705.

Adeyeye, E.I., Ayejuyo, O.O. 2007. Proximate, amino acid and mineral composition of Turkey-hen muscle and skin. Oriental Journal of Chemistry, 23: 879-886.

Adeyeye, E.I., Asaolu, S.S., Aluko, A.O. 2007. Amino acids composition of two masticatory nuts (Cola acuminata and Garcinia kola) and snack nut (Anacardium occidentale). Internation Journal of Food Sciences and Nutrition, 58: 241-249.

Adeyeye, E.I., Adamu, A.S. 2005. Chemical composition and food properties of Gymnarchus niloticus (Trunk fish). Bioscience Biotechnology Research Asia, 3: 265-272.

Adeyeye, E.I. 2005a. Amino acid composition of variegated grasshopper, Zonocerus variegatus. Tropical Science, 45: 141-143.

Adeyeye, E.I. 2005b. The composition of winged termites, Macrotermes bellicosus. Journal of the Chemical Society of Nigeria, 30: 145-149.

Adeyeye, E.I. 2004. The chemical composition of liquid and solid endosperm of ripe coconut. Oriental Journal Chemistry, 20: 471-476.

Adeyeye, E.I., Afolabi, E.O. 2004. Amino acid composition of three different types of land snails consumed in Nigeria. Food Chemistry, 85: 535-539.

Alsmeyer, R.H., Cunningham, A.E., Happich, M.L. 1974. Equation to predict PER from amino acid analysis. Food Technology, 28: 34-40.

AOAC, 2006. Official Methods of Analysis of AOACInternational, $18^{\text {th }}$ edition, Association of Official Analytical Chemists, Washington, DC., USA.

Bingham, S. 1977. Dictionary of Nutrition, pp. 76-281, Barrie and Jenkin Limited, London, UK.

Davidson, A. 1999. The Oxford Companion to Food, Oxford University Press, Oxford, UK.

Eubanks, L.P., Middlecamp, C.H., Heltzel, C.E., Keller, S.W. 2009. Chemistry in Context: Applying Chemistry to Society, $6^{\text {th }}$ edition, McGraw Hill Higher Education, Boston, USA.

FAO/WHO, 1973. Energy and Protein Requirements, Report of a Joint FAO/WHO Adhoc Expert Committee, WHO, Technical Report Series No. 522, Geneva, Switzerland.

FAO/WHO, 1990. Protein Quality Evaluation, Report of Joint FAO/WHO Consultation, FAO/UNO, Rome, Italy.

FAO/WHO, 1991. Protein Quality Evaluation, FAO Food Nutrition Paper No. 51, FAO/WHO, Report of Joint FAO/WHO Expert Consultation, Bethesda, Md., USA.

FAO/WHO/UNU, 1985. Energy and Protein Requirements, Report of a Joint FAO/WHO/UNU Expert Consultation, WHO Technical Report Series No. 724, Geneva, Switzerland.

Finar, I.L. 1975. Organic Chemistry, vol. 2, $5^{\text {th }}$ edition, ELBS and Longman Group, London, UK. 
Fornias, O.V. 1996. Edible By-Products of Slaughter Animals, vol. 123, 153 pp., FAO Animal Production and Health Paper Series 123, FAO of United Nations, Rome, Italy.

Mendoza, C. 2002, Effect of genetically modified low phytic acid plants on mineral absorption. International Journal of Food Science \& Technology, 37: 759-767.

Moore, S., Spackman, D.H., Stein, W.H. 1958. Chromatography of amino acids on sulphonated polystyrene resins: An improved system. Analytical Chemistry, 30: $1185-1190$.

Nielsen, S.S. 2002. Introduction to the Chemical Analysis of Foods, CBS Publishers and Distributors, New Delhi, India.

Olaofe, O., Akintayo, E.T. 2000. Prediction of isoelectric points of legume oilseed proteins from their amino acid composition. The Jaurnal of Technoscience, 4: 49-53.

Olaofe, O., Adeyemi, F.O., Adediran, G.O. 1994. Amino acid and mineral compositions and functional properties of some oilseeds. Journal of Agricultural and Food Chemistry, 42: 879-881.

Oloyo, R.A. 2001. Fundamentals of Research Methodology for Social and Applied Sciences, pp. 71-73, ROA Educational Press, Federal Polytechnich, Ilaro, Nigeria.

Oyarekua, M.A., Adeyeye, E.I. 2011. The amino acids profile of the brain and eyes of African giant pouch rat (Cricetomys gambianus). Agriculture and Biology Journal of North America, 2: 368-375.

Oyarekua, M.A., Eleyinmi, A.F. 2004. Comparative evaluation of the nutritional quality of corn, sorghum and millet ogi prepared by modified traditional technique. International Journal of Food, Agriculture and Environment, 2: 94-99.

Paul, A.A., Southgate, D.A.T. 1978. McCance and Widdowson's The Composition of Foods, $4^{\text {th }}$ edition, Her Majesty's Stationery Office, London, UK.

Pearson, D. 1976. Chemical Analysis of Foods, pp.7$12,7^{\text {th }}$ edition, Churchill Livingstone, London, UK.

Rose, W.C. 1949. Amino acid requirements of man. Federation Proceedings, 8: 546-552.

Salunkhe, D.K., Kadam, S.S. 1989. Handbook of World Food Legumes: Nutritional Chemistry, Processing Technology and Utilization, CRC Boca Raton Press, Florida, USA.

Sandström, B., Almgren, A., Kivisto, B., Cederblad, A. 1989. Effect of protein level and protein source on zinc absorption in humans. The Journal of Nutrition, 119: 48-53.

Schorger, A.W. 1966. The Wild Turkey Its History and Domestication, 625 pp., $1^{\text {st }}$ edition, University of Oklahoma Press, Norman, OK., USA.

Shagun, B.de. 1590. General History of the Things of New Spain: Florentine Codex, School of American Research, (1950-1982), Santa Fe, New Maxico.

Steinke, F.H., Prescher, E.E., Hopkins, D.T. 1980. Nutritional evaluation (PER) of isolated soybean protein and combinations of food proteins. Journal of Food Science, 45: 323-327.

White, A. Handler, P., Smith, E.L. 1973. Principles of Biochemistry, 853 pp., $5^{\text {th }}$ edition, McGraw Hill, New York, USA.

Yuwai, K.E., Rao, K.S., Kaluwin, C., Jones, G.P., Rivett, D.E. 1991. Chemical composition of Monerdica charantis L. fruits. Journal of Agricutural and Food Chemistry, 39: 1762-1763. 